\title{
KECERNAAN GLOBAL FRAKSI NITROGEN UNTUK 11 BAHAN MAKANAN TERNAK
}

\author{
Kustantinah
}

\section{INTISARI}

Percobaan ini bertujuan untuk menentukan korelasi antara komposisi kimia hịjauan pakan, khususnya fraksi nitrogen dinding sel dan kecernaan glohal fraksi nitrogen total. Sebanyak 11 hijauan yang mempunyai komposisi kimia herbeda dideterminasi kecernaan glohalnya secara in vivo dengan menggunakan 5 ekor domba. Dari keseluruan hijauan makanan ternak yang dipelajari rata-rata kecernaan global semu untuk protein, adalah $70,4 \%$ dengan koefisien variasi (KV) yang cukup tinggi $17,5 \%$. Kecernaan semu protein (nitrogen total) adalah cukup erat hubungannya dengan kadar protein yang hersangkutan $(r=-0,828 ; n=11)$, dengan kadar Neutral Detergent Insoluble Nitrogen (NDIN) $(\mathrm{r}=-0,758 ; \mathrm{n}=9)$ ataupun dengan kadat Acid Detergent Insoluble Nitrogen (ADIN) $(r=-0,88 ; n=9)$. Dengan percobaan ini pula dinyatakan bahwa penggunaan nitrogen dinding sel di dalam feses sebagai nilai indikator dari nitrogen pakan yang tidak tercerna, dapat digunakan untuk mengestimasikan koefisien kecernaan global protein pakan ternak yang rata-ratanya adalah $89,1 \%(\mathrm{KV}=6,3 \%$ tetapi tidak timbul suatu korelasi dengan proporsi ADIN/Nt $(r=-0,039 ; n=9)$ dan proporsi NDIN/Nt $(r=-0,275$; $\mathrm{n}=9$ ).

(Kata kunci: Kecernaan, hịjauan, nitrogen, domba.)

\section{ABSTRACT}

The purpose of this trial was to determined the correlation between forage composition, especially nitrogen $(\mathrm{N})$ fraction cell-wall, and its digestibility of total $\mathrm{N}$ fraction. Eleven herhages with different chemical composition were determined the in vivo digestibility using five sheep in total collection technique. From all the herhages examined, the average of apparent digestiblity of the protein was $70.4 \%$ with coefficient of variability (CV) of $17.5 \%$. The correlation between apparent digestibility of protein with total $N(r=-0.828 ; n=11)$ with NDIN $(r=-0,758 ; n=9)$ and with ADIN $(r=0,688 ; n=9)$ were tight. This trial stated that cell wall-N in the feces, as an indication of undigested- $\mathrm{N}$, can be used to estimate total true digestibility coefficient feed protein. The coefficient value was $89,1 \%(\mathrm{CV}=6.3)$, but not correlated with the proportion of $A D I N / N_{T}(r$ $=-0.039 ; \mathbf{n}=9)$ and NDIN/N, $(r=-0.275 ; n=9)$.

(Key words: Digestibility, herbage, nitrogen, sheep.)

\footnotetext{
' Fakultas Peternakan UGM, Yogyakarta 55281
} 


\section{Pendahuluan}

Kompleks ligno-selulose adalah komponen tanaman yang paling sulit dicerna. Oleh karenanya, fraksi nitrogen yang terikat di dalam kompleks tersebut merupakan fraksi nitrogen yang juga kurang tercerna. Menurut Krishnamoorthy et al. (1982a) dan Krishnamorrthy ot al. (1982b), nitrogen yang tidak larut di dalam larutan deterjen netral dari Van Soest (NDIN) adalah bagaian fraksi protein kasar yang tercerna secara lambat. Sedangkan nitrogen yang tidak larut di dalam larutan deterjen asam dari Van Soest. (ADIN) adalah fraksi yang sama sekali tidak bisa dimanfaatkan. Tamminga (1983) menyatakan. bahwa protein yang tidak larut di dalam larutan deterjen dari Van Soest, dapat disebut protein struktural sedangkan protein cadangan (sitoplasma) adalah fraksi yang larut di dalam larutan deterjen tersehut.

Mason $(1969,1979)$ menyatakan hahwa ekstraksi dengan menggunakan larutan deterjen netral dapat menyehahkan eliminasi dari nitrogen yang berasal dari bakteri yang terdapat di dalam feses. Fraksi NDIN yang diperoleh Mason (1969, 1979) dan Weiss et al. (1986) dapat digunakan mengestimasi kuantitas nitrogen bahan pakan ternak yang tidak tercerna di dalam saluran pencernaan. Hal tersebut dikuatkan oleh Van Soest (1982) yang menyatakan bahwa nitrogen yang terkandung di dalam fraksi Neutral Dertergent Fiher (NDF) terutama terdiri dari nitrogen bahan pakan yang tidak tercerna dan juga komplek protein-tanin. Dengan demikian kuantitas nitrogen dinding sel di dalam hijauan pakan dapat digunakan sebagai markah untuk meramalkan kecernaan nitrogen. Persyaratan utama dari penggunaan kriteria tersebut adalah (1) penyeharan nitrogen di dalam heherapa fraksi dinding sel tanaman yang berbeda harus cukup hervariasi untuk dapat menciptakan suatu klas hahan pakan ternak, dan (2) kecernaan nitrogen harus secara efektif herhubungan dengan fraksi-fraksi nitrogen di dalam hijauan pakan.

Untuk menguatkan apakah kondisi yang disebutkan di atas dapat terpenuhi, maka dilakukan penelitian herikut ini. Di dalam percohaan ini diukur kadar nitrogen total (PK), NDIN, ADIN, juga penggunaan pencernaan secara in wivo dari fraksifraksi tersehut. Untuk merealisasikan penelitian di atas digunakan 11 hijauan pakan dengan mempertimbangkan ketersediaan dan keaneka- ragaman, komposisi kimianya.

\section{Materi Dan Metode}

Sebelas macam hijauan pakan (Tabel dianalisis untuk mengetahui kandungan bahı keringnya $(\mathrm{BK})$, bahan organik $(\mathrm{BO})$, fraksi dindi sel (NDF dan ADF), nitrogen total (PK) dan frak nitrogen dinding sel (NDIN dan ADIN) dan jus fraksi nitrogen yang larut (NS) di dalam larute mineral dari Verite dan Demarquilly (1978).

Kecernaan BK dan komposisi bahan keris lainnya diukur dengan metode in vivo (Dermarquilly 1969). Percohaan kecernaan ini dilakukan denga menggunakan lima ekor domba jantan dewasa jeni Texel. Domba-domba tersebut diletakkan di dalan kandang khusus untuk pengukuran kecernaan. Paka diherikan secara individual sehanyak dua kali pe hari. Kuantitas makanan yang diberikan ditentuka sedemikian rupa supaya kuantitas bahan kering yam tidak dikonsumsi sekitar $10 \%$ dari yang disediakan Setelah periode adaptasi makanan yang berlangsun selama tiga minggu, kuantitas makanan yan diberikan, kuantitas makanan yang dikonsumsi dat juga kuantitas total feses yang diproduksi ditimban untuk setiap domba selama 10 hari secara berturut turut. Selama periode pengukuran kecernaan ini sampel makanan yang diberikan, sampel makanat yang tersisa dan satu sampel feses harian untuk setia domba diambil (sekitar 100 atau 200 gram setia sampel) dan dikeringkan di dalam oven pada suht $80^{\circ 1} \mathrm{C}$ selama 48 jam, kemudian dianalisis.

\section{Hasil Dan Pembahasan}

\section{Komposisi Kimia Bahan Pakan}

Kadar dinding sel total (NDF) dari 11 hijatuan pakan hervariasi clari $35 \%$ untuk kuhis jenis cavalier merah, sampai dengan $68 \%$ untuk silas rumput yang tumbuh di padang penggembalaan $\{2$ (Tabel 1). Silase rumput ini dan juga Silase Seigle (Ing:Rye), merupakan hịjauan yang mengandung kadar ADF paling besar. Kadar PK adalah antara 7,7 sampai $23 \%$. NDIN/NT bervariasi dengan kisaran yang lehih besar. Kadar yang paling rendah ditemukan untuk kubis jenis moelliers kontrol $15,7 \mathrm{~g}$
TABEL 1. KOM

Hịaua

Silase jagung 1

Silase jagung 2

Rumput yang tu penggembalaan Silase rumput $p$ penggembalaan Silase rumput $p$ penggembalaa

Alfalt

Hijauan Seigle Silase seigle

Kubis jenis cav berwarna mera

Kubis jenis mo Kubis jenis mo $160 \mathrm{uN} / \mathrm{ha}$ ).

I Nitrogen yang to

TABEL 2. RA

Karakter

PK/BK

NDF/BK

ADF/BK

NDIN/NT

ADIN/NT NDIN/ADIN ADIN/NDIN

dan kadar yang tum ADIN/N dengan NI untuk hijat 
TABEL 1. KOMPOSISI KIMIA DARI II HIJAUAN MAKANAN TERNAK

\begin{tabular}{|c|c|c|c|c|c|c|c|c|}
\hline \multirow{2}{*}{ Hịatuan } & \multirow{2}{*}{$\begin{array}{l}\mathrm{BK} \\
\%\end{array}$} & \multicolumn{4}{|c|}{ \% BK } & \multicolumn{3}{|c|}{ \% NT } \\
\hline & & $\mathrm{BO}$ & NDF & ADF & PK & NDIN & ADIN & NS \\
\hline Silase jagung I & 29,3 & 95,9 & 55,5 & 21,1 & 7,7 & 18,8 & 6,0 & 47,5 \\
\hline Silase jagung 2 & 21,8 & 94,6 & 51,6 & 24,4 & 9,7 & 22,8 & 8,0 & 49,6 \\
\hline $\begin{array}{l}\text { Rumput yang tumbuh dipadang } \\
\text { penggembalaan } \\
\text { Silase rumput padang }\end{array}$ & 19,4 & 82,0 & 51,9 & 29,6 & 23,1 & 44,3 & 8,3 & 21,0 \\
\hline $\begin{array}{l}\text { Silase rumput padang } \\
\text { penggembalaan } 1\end{array}$ & 29,2 & 85,6 & 61,6 & 36,7 & 13.7 & 30,7 & 10,8 & 52,5 \\
\hline $\begin{array}{l}\text { Silase rumput padang } \\
\text { penggembalaan } 2\end{array}$ & 30,0 & 90,9 & 68,5 & 45,0 & 9,7 & 25,3 & 14,9 & 66,1 \\
\hline Alfalfa & 88,9 & 90.5 & 50,1 & 41,0 & 15,2 & 21,4 & 9,2 & 34,1 \\
\hline Hijauan Seigle (Ing: Ry) & 18,9 & 93,7 & 61,1 & 33,1 & 10,5 & 40,5 & 5,6 & 28,8 \\
\hline Silase seigle & 26,0 & 86,3 & 63,4 & 45,3 & 10,5 & 18,0 & 6,8 & 56,0 \\
\hline $\begin{array}{l}\text { Kubis jenis cavalier yang } \\
\text { herwarna merah. }\end{array}$ & 17,5 & 89,5 & 35,8 & 27,9 & 14,1 & 19,7 & 7,4 & 40,2 \\
\hline Kubis jenis moelliers (kontrol) & 14,9 & 88,1 & 37,5 & 26.2 & 14,9 & 15,7 & 4,8 & 47,0 \\
\hline $\begin{array}{l}\text { Kuhis jenis moelliers (dipupuk, } \\
160 \mathrm{uN} / \mathrm{ha} \text { ). }\end{array}$ & 13,3 & 87,1 & 36,0 & 26,9 & 17,9 & 24,8 & 7,0 & 37,9 \\
\hline
\end{tabular}

${ }^{1}$ Nitrogen yang terlarut (Ns) di clilam larulan mineral dari Verite dan Demaryuilly (1978).

TABEL 2. RATA-RATA, DAN KOEFISIEN DARI VARIASI $(K . V)$ KRITERIA POKOK DARI KOMPOSISI KIMIA $(n=11)$

\begin{tabular}{lcc}
\hline \hline Karakter & Rata-rata & K.V $(\%)$ \\
\hline PK/BK & $13,4 \pm 4,4$ & 33,1 \\
NDF/BK & $52,1 \pm 11,5$ & 22,1 \\
ADF/BK & $32,5 \pm 25,8$ & 25,8 \\
NDIN/NT & $25,6 \pm 36,3$ & 36,3 \\
ADIN/NT & $8,1 \pm 34,8$ & 34,8 \\
NDIN/ADIN & $17,6 \pm 9,3$ & 53,0 \\
ADIN/NDIN & $33,7 \pm 11,9$ & 35,4 \\
\hline
\end{tabular}

dan kadar yang paling besar di temukan untuk rumput yang tumbuh di padang penggemhalaan $44,3 \%$. ADIN/N , hervariasi lebih sempit dibandingkan dengan NDIN/N Taitu antara $4,8 \%$ dengan $14,9 \%$ untuk hịauan pakan yang sama.
Untuk keanekaragaman pakan ditunjukkan dengan pertolongan parameter statistik simpel (Tabel 2). Variasi yang paling hesar ditemukan untuk fraksitraksi nitrogen (NDIN/N $, A D I N / N_{T}, A D I N / N D I N$, NDIN-ADIN dan $\mathrm{N}_{\mathrm{s}} / \mathrm{N}_{\mathrm{T}}$ ) dibandingkan fraksi NDF 
TABEL 3. KOEFISIEN KORELASI ANTARA FRAKSI BAHAN MAKANAN $(\mathbf{r}, \mathbf{n}=11)$

TABEL 5. KE

\begin{tabular}{lllll}
\hline Fraksi & NDIN/Nt & ADIN/Nt & ADIN/NDIN & Ns/Nt \\
\hline PT/BK & 0,4 & $-0,06$ & $-0,372$ & $-0,658$ \\
NDF/BK & 0,309 & 0,517 & 0,248 & 0,400 \\
ADF/BK & 0,047 & 0,596 & 0,520 & 0,353 \\
ADF/NDF & $-0,281$ & 0,017 & 0,328 & 0,039 \\
NDIN/Nt & - & 0,137 & 0,568 & $-0,594$ \\
ADIN/Ni & - & - & 0,724 & $-0,139$ \\
\hline
\end{tabular}

TABEL 4. KONSUMSI DAN KECERNAAN DARI II HIJAUAN MAKANAN TERNAK

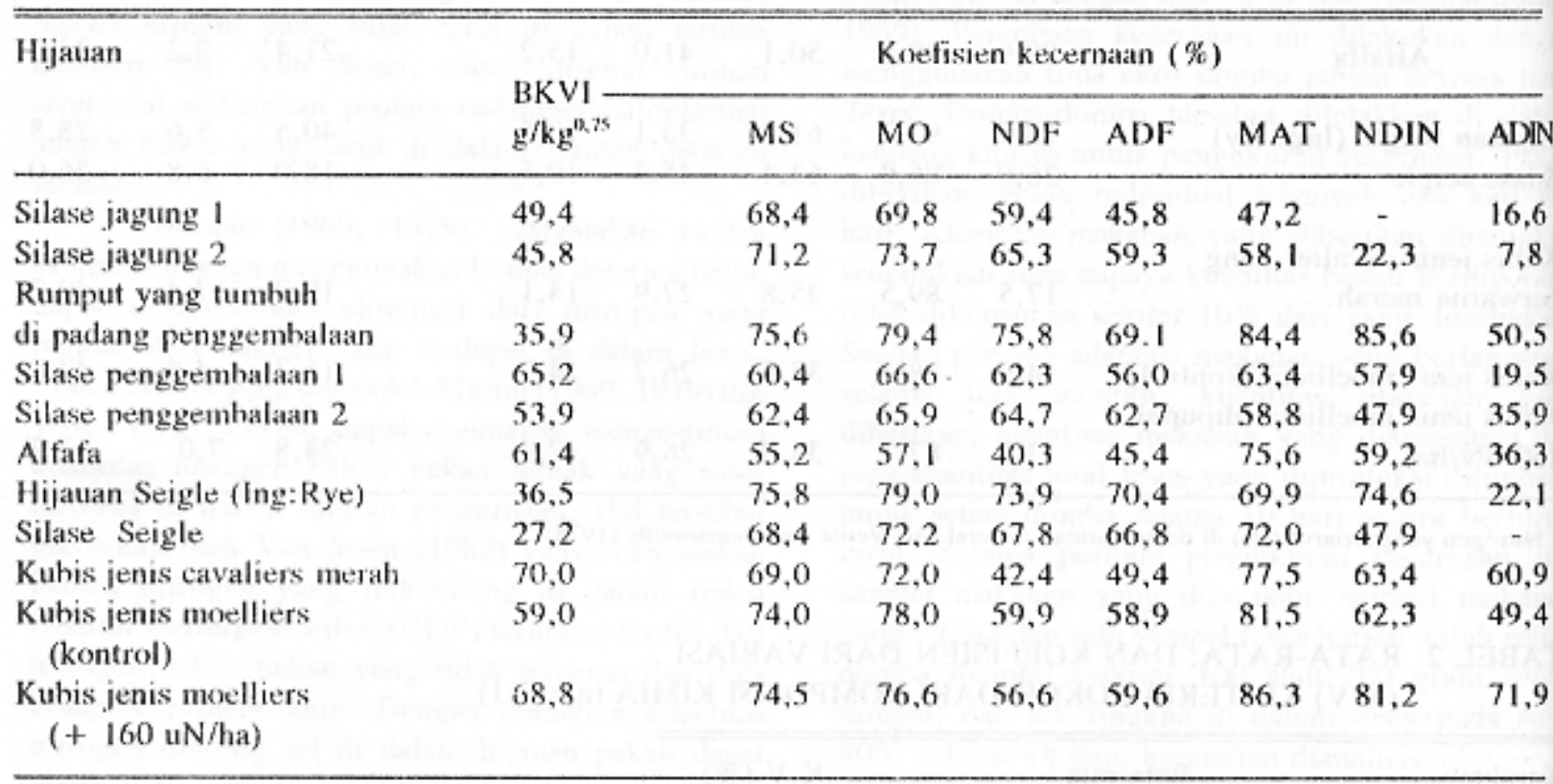

dan fraksi ADF. Fraksi nitrogen yang terikat dengan fraksi hemiselulose (NDIN-ADIN) merupakan fraksi yang menunjukkan koefisien variasi yang paling hesar diantara fraksi bahan makanan yang lain. Variahilitas fraksi nitrogen yang cukup hesar juga telah ditunjukkan oleh Krishmoorthy of al. (1982) dengan menggunakan bahan makanan yang berheda, yaitu 10 macam konsentrat dan 6 macam hijauan. Peneliti ini menunjukkan suatu variasi fraksi nitrogen yang sangat kuat dibandingkan dengan fraksi struktural dari dinding sel (ditunjukkan dengan koefisien variasi $=$ KV) yaitu: KV. NDIN/NT: 72,4\% vs KV. NDF/BK: $58.9 \%$, dan KV. ADIN/NT: $80 \%$ vs K.V. ADF/BK:
$67,6 \%$

Dari seluruh pakan yang dipelajari, korelasi antara $N D I N / N_{1}$ dan $A D I N / N_{t}$ dengan nilai $P K$ adalah sangat kecil (Tahel 3). Daya tahan fraksi nitrogen dan hahan kering terhadap kelarutannya di dalam larutan deterien acid (ADS) dari Van Soest terlihat saling berkorelasi $(r=0,596)$ tetapi sehaliknya, NDIN/NT hanya sedikit berkorelasi dengan NDF/BK $(r=0,309)$. Persamaan regresinya adalah sebagai berikut:

ADIN $/ N_{\mathrm{T}}=0,15$ ADF/BK - 3,41 $\quad(\mathbf{r}=0,60 ; n$

$=$ (1), dan

NDIN $/ N_{r}=0,25 \mathrm{NDF} / \mathrm{BK}-12,63 \quad(\mathrm{r}=0,31 ; \mathrm{n}$ $=1 !$ )
Hijauan

Silase jagung Silase jagung Rumput yang Silase penggen Silase penggen Alfafa Hijauan Seigle Silase Seigle Kubis jenis ca Kubis jenis m Kubis jenis me
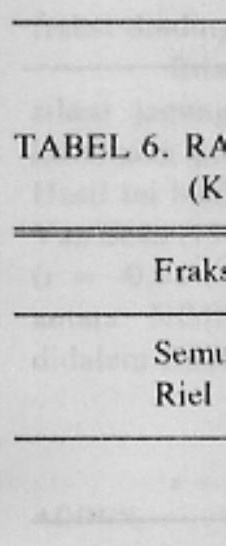

Korelasi antar mineral (Ns), kelarutan di c adalah :

$\mathrm{Ns} / \mathrm{N}_{\mathrm{T}}=0,83$

Dari hal ter berikatan deng terikat dengan sangat kecil komposisi kin kadar BK, PK

Kecernaan G

Untu dipelajari, kec alfalfa kering 4). Bahan mak 
TABEL 5. KECERNAAN GLOBAL SEMU DAN KECERNAAN GLOBAL RIEL UNTUK PROTEIN

\begin{tabular}{lcc}
\hline \hline Hijauan & \multicolumn{2}{c}{ Kecernaan glohal protein $(\%)$} \\
\cline { 2 - 3 } & Semu & Riel \\
\hline Silase jagung 1 & 47,2 & 79,4 \\
Silase jagung 2 & 58,1 & 82,3 \\
Rumput yang tumbuh di padang penggembalaan & 84,8 & 93,6 \\
Silase penggembalaan (1) & 63,4 & 90,5 \\
Silase penggembalaan (2) & 58,8 & 89,6 \\
Alfafa & 75,6 & 82,8 \\
Hijauan Seigle (Ing: Rye) & 69,9 & - \\
Silase Seigle & 72,0 & - \\
Kubis jenis cavvaliers merah & 77,5 & 92,8 \\
Kubis jenis moelliers kontrol & 81,5 & 94,1 \\
Kubis jenis molliers (= 160 uN/ha & 86,3 & 95,3 \\
\hline
\end{tabular}

TABEL 6. RATA-RATA, DAN KOEFISIEN VARIASI (KV) DARI KECERNAAN PROTEIN

\begin{tabular}{llc}
\hline \hline Fraksi & Ratat-rata & KV $(\%)$ \\
\hline Semu & $70,4 \pm 12,3$ & 17,5 \\
Riel & $89,1 \pm 5,6$ & 6,3 \\
\hline
\end{tabular}

Korelasi antara bagian yang terlarut di dalam larutan mineral (Ns), korelasi antara parameter ini dan kelarutan di dalam larutan deterjen netral (NDSN) adalah :

$\mathrm{Ns} / \mathrm{N}_{\mathrm{T}}=0,83 \mathrm{NDSN} / \mathrm{N}_{\mathrm{r}}-17,7(\mathrm{r}=0,60 ; \mathrm{n}=11)$. Dari hal tersebut diatas, fraksi nitrogen yang berikatan dengan dinding sel total (NDIN) atau yang terikat dengan komplek ligno-selulosa (ADIN) adalah sangat kecil korelasinya dengan karakteristik komposisi kimia hahan pakan ternak seperti kadarkadar BK, PK, NDF, dan ADF (Tabel 3).

\section{Kecernaan Global}

Untuk sebelas macam hijauan pakan yang dipelajari, kecernaan BK berkisar antara $55 \%$ untuk alfalfa kering dan $75,8 \%$ untuk hịauan $S$ eigle (Tabel 4). Bahan makanan yang memberikan kecernaan BK paling rendah adalah pakan yang mempunyai kecernaan dari fraksi-fraksi NDF dan ADF yang paling rendah. Alfafa kering, memberikan kecernaan fraksi NDF sekitar $40 \%$ dan kecernaan fraksi ADF sekitar $45 \%$. Sehaliknya, kecernaan fraksi NDF dan ADF yang paling tinggi di temukan pada rumput yang tumbuh di padang penggembalaan (masingmasing adalah sebesar 75,8 dan $70,1 \%$ ).

Kecernaan PK adalah sekitar $47,2 \%$ untuk silase jagung 1 dan $86 \%$ untuk kubis jenis moelliers yang mendapat pemupukan (160 uN/Ha). Untuk kecernaan nitrogen total (PK), nitrogen (NDIN dan nitrogen yang terikat ke dalam fraksi ADF (ADIN) bervariasi secara paralel untuk hijauan yang berbedabeda. 
TABEL 7. KECERNAAN GLOBAL YANG TERLIHAT DARI NITROGEN DINDING SEL (NDIN) DAN NITROGEN LIGNOCELLULOSE (ADIN)

\begin{tabular}{lcc}
\hline \hline Hijauan & \multicolumn{2}{c}{ Kecernaan glohal semu (\%) } \\
\cline { 2 - 3 } & NDIN & ADIN \\
\hline Silase jagung 1 & TD & 16,6 \\
Silase jagung 2 & 22,3 & 7,8 \\
Rumput yang hidup di padang penggembalaan & 85,6 & 50,5 \\
Silase penggembalaan (1) & 57,9 & 19,5 \\
Silase penggembalaan (2) & 47,9 & 35,9 \\
Alfafa kering & 59,2 & 36,3 \\
Hijauan Seigle (Ing:Rye) & 74,6 & 22,1 \\
Silase Seigle & 47,8 & TD \\
Kubis jenis cavaliers merah & 63,4 & 60,9 \\
Kubis jenis moelliers kontrol & 62,3 & 49,4 \\
Kubis jenis moelliers (= 160 uN/ha) & 81,2 & 71,9 \\
\hline
\end{tabular}

"Tidak didelerminasi

TABEL 8. RATA-RATA, DAN KOEFISIEN VARIASI (KV) DARI KECERNAAN FRAKSI ADIN DAN NDIN

\begin{tabular}{lll}
\hline \hline Fraksi & Rata-rata & KV $(\%)$ \\
\hline NDIN $(\mathrm{n}=10)$ & $60,2 \pm 18,4$ & 30,6 \\
ADIN $(\mathrm{n}=10)$ & $37,1 \pm 20,9$ & 56,3
\end{tabular}

Hubungan Antara Kecernatan Protein Total dan Kadar Fraksi Nitrogen

Dari keselurahan hijauan makanan ternak yang dipelajari, kuantitas nitrogen feses herhubungan sangat erat dengan kuantitas nitrogen $A D I N$, tetapi hal tersebut hanya ditemukan di dalam sembilan dari sebelas bahan makanan yang diteliti, sedangkan keduat silase jagung memberikan hasil yang berbeda. Berdasarkan sembilan hijauan makanan ternak (tanpa silase jagung 1 dan 2), korelasi antara kualitas ransum dan produksi nitrogen feses dapat disajikan sebagai herikut:

$$
\text { Konsumsi ADIN } \mathrm{r}=0,837 \quad \mathrm{NDIN} \text { feses } \frac{\mathrm{r}=0,983}{-\mathrm{N} \text {, feses }}
$$$$
\text { Konsumsi ADIN } \frac{r=0.819}{-} N \text {, feses }
$$

Untuk seluruh bahan makanan yang dipelajari, kecernaan global semu untuk PK, rata-rata adalah $70,4 \%$ dengan koefisien variasi yang cukup tinggi $(17,5 \%)$. Nilai paling rendah, ditemukan pada silase jagung I $(47,2 \%)$ dan nilai yang paling besar ditemukan pada kubis jenis moelliers $(86,3 \%)$ yang menclapat pemupukan ( $160 \mathrm{uN} / \mathrm{ha}$ ). Kecernaan tersebut berhubungan nyata $(P<0,001)$ dengan kuantitas PK pakan ( $\mathrm{r}=0,828, \mathrm{n}=11$ ), tetapi sangat kecil korelasinya (r) dengan proporsi NDIN dan ADIN (0,187 dan 0,285). Demikian juga, kecernaan NDIN adalah sangat kecil korelasinya dengan ADIN. Seperti yang diamati sebelumnya, diantara seluruh hahan pakan yang dipelajari, silase jagung 1 dan 2 mempunyai sifat khusus (Gambar 1), yang kemungkinan karena pada hewan yang hanya menerima pakan silase jagung kondisi fermentasi di dalam rumen, ditinjau dari tersedianya $\mathrm{N}$ amonia, tidak menungkinkan untuk mencerna dinding sel dan
Gambar 1. R (a) dan relasi

fraksi dinding

Bila

silase jagung kecernaan pro Hasil ini lebil Van Soes (19: $(\mathbf{r}=-0,51 ;$ antara NDIN didalam frak

ADIN/N

$r=$

ADIN /NDIN -

Nitr

indikasi dari tercerna, dap koefisien kec rata-ratanya a variasi cuku rendah ditem nilai yang $p$ moellier yang sangat dekat (1986) yang $r$ dari fraksi ni $86 \%$, bertu dipanaskan, Untuk selur 
(a)

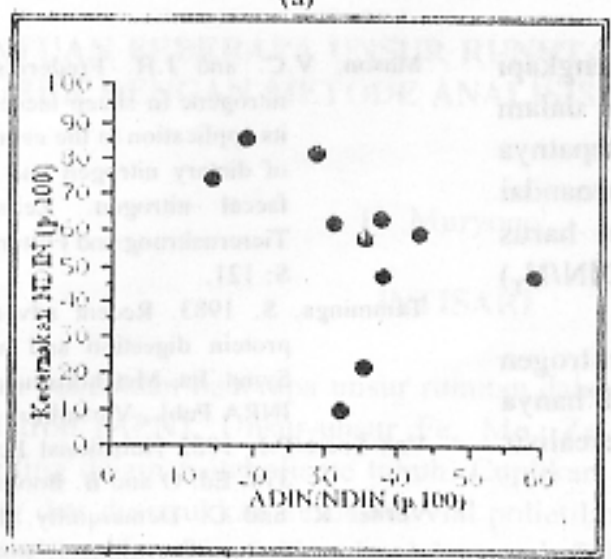

(b)

ISSN 0I26-4400

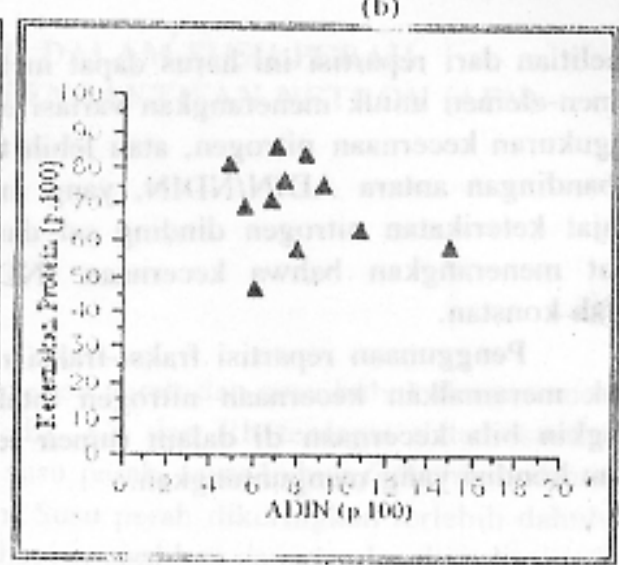

Gambar 1. Relasi antara hagian fraksi ADIN didalam fraksi NDIN (ADIN/NDIN dan kecernaan fraksi NDIN (a) dan relasi antara kadar ADIN dan kecernatan protein (b).

fraksi dinding sel secara keseluruhan.

Bila kita tidak memperhitungkan kedua silase jagung tersebut, korelasi ADIN/Nt dengan kecernaan protein menjadi lebih erat $(r=-0,688)$. Hasil ini lebih tinggi dari pada yang ditemukan oleh Van Soes (1982) untuk hijauan yang tidak dipanaskan $(\mathrm{r}=-0,51 ; \mathrm{n}=28)$. Demikian pula untuk korelasi antara NDIN/N $\mathrm{N}_{\mathrm{T}}$ dan bagian dari fraksi ADIN didalam fraksi NDIN (ADIN/NDIN) $(r=-0,803)$.

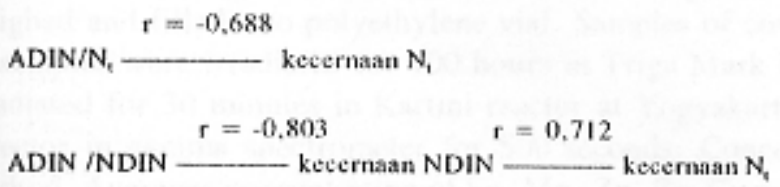

Nitrogen dinding sel feses, sehagai nilai indikasi dari nitrogen bahan makanan yang tidak tercerna, dapat digunakan untuk mengestimasikan koefisien kecernaan global nyata untuk protein yang rata-ratanya adalah $89,1 \%$ (Tahel 5) dengan koefisien variasi cukup rendah $(6,3 \%)$. Nilai yang paling rendah ditemukan pada silase jagung $(79,4 \%)$ dan nilai yang paling hesar ditemukan pada kubis jenis moellier yang dipupuk $(95,3 \%)$. Nilai-nilai tersebut sangat dekat dengan yang ditemukan oleh Weiss et al (1986) yang menyatakan hahwa kecernaan glohal riel dari fraksi nitrogen totalnya adalah 94,$0 ; 88,0$ dan $86 \%$, berturut-turut untuk alfafa yang tidak dipanaskan, dipanaskan pada suhu $35^{\circ} \mathrm{C}$ dan $60^{\prime \prime} \mathrm{C}$. Untuk seluruh bahan makanan yang dipelajari kecernaan global semu NDIN rata-rata adalah $60,2 \%$ dengan koefisien variasi sangat kuat $(30,6 \%)$. Nilai yang rendah ditemukan pada silase jagung $2(22,3 \%)$ dan nilai yang paling besar ditemukan di rumput yang tumbuh di padang penggembalaan (sekitar $85,6 \%$ ). NDIN ini berhubungan secara significatif $(\mathrm{P}<0,001)$ dengan kadar nitrogen dinding sel bahan makanan ( $r$ $=0,98 ; \mathrm{n}=11)($ Tabel 7).

Variasi antar pakan, dari kecernaan global semu untuk ADIN adalah lehih kuat dibandingkan dengan variasi PK atau fraksi NDIN. Nilai yang paling kecil ditunjukkan silase jagung $2(7,8 \%)$ dan nilai yang paling besar ditunjukkan oleh Kubis jenis moelliers yang mendapat pemupukan $(71,9 \%)$. Bila diperhitungkan estimasi dari kecernaan global riel PK, tidak timbul suatu korelasi dengan proporsi ADIN/NT $(r=0,039)$ observasi ini cenderung menyatakan bahwa perbedaan kecernaan yang diamati ditingkat rumen, dan yang berhubungan dengan proporsi ADIN/NT seperti yang dinyatakan oleh Lejeune (1985), mungkin diimbangi dengan kecernaan yang berlangsung di dalam saluran pencernaan bagian bawah.

\section{Kesimpulan}

Pembagian nitrogen tumbuh-tumbuhan ke dalam beberapa fraksi tergantung kelarutannya di dalam larutan deterjen dari Van Soest, dan ini merupakan suatu kriteria yang dapat membuktikan keterikatan protein oleh polisakarida struktural. 
Penelitian dari repartisi ini harus dapat melengkapi elemen-elemen untuk menerangkan variasi di dalam pengukuran kecernaan nitrogen, atau lebih tepatnya perbandingan antara ADIN/NDIN, yang menandai derajat keterikatan nitrogen dinding sel dan harus dapat menerangkan bahwa kecernaan $\left(\mathrm{NDIN} / \mathrm{N}_{\mathrm{T}}\right)$ adalah konstan.

Penggunaan repartisi fraksi-fraksi nitrogen untuk meramalkan kecernaan nitrogen total hanya mungkin bila kecernaan di dalam rumen terealisir dalam kondisi yang menguntungkan.

\section{Daftar Pustaka}

Krishnamoorthy U., V. Muscato .. CJ. Sniffen, and P.J. Van Soest, 1982. Nitrogen content of ruminants feedstufr. J. Dairy Sci. 65:217.

Krishnanoorthy, U., C.J. Sniffen., and P.J Van Socst. 1982. Nitrogen fractionation in ruminats feedstuff foy feed evaluation. Can. Nut. Conf. Feed Manf. Pruc, 95.

Lejeune, C.V. 1985. Fermentation des matieres azostees alimentaires dans le rumen.. These, INPI. Nancy.

Mason. V.C. 1986. Some observations on the distribution and origin of nitrogen in sheep factes, J. Agric. Sci. (Camb) $73: 99$.
Mason. V.C. and J.H. Frederikson. 1979. Partition of the nitrogene in sleep fneees with delergent solution an its application to the estimation of the Ine digestibilit of dietary nitrogen and the excretion of non diets? faecal nitrogen. Zeitschriff fur tierphysiologis Titrernahrung und Futtermittelkunde. Band 41. Heft 3 S: 121.

Tamminga. S. 1983. Recent advanves in our knowledges o protein digestion and absorption in ruminants. 4 . Symp. Int. Metaholisme et nutrition azotes, 1,263. Ef INRA Publ., Versailles.

Van Soest P.J. 1982 Nutritional Ecology of the Ruminant, $p p$ 374. Ed. $O$ and B. Books, Corvallis.

Verite, R. and C. Denarquilly. 1978. Qualite des matierst azotees des aliments pour ruminants. In: La vach laitiere. p.143-158. Ed. INRA Publications Route d S1-Cry-7800 Versailles.

Wciss, W.P., H.R. Conrad, and W.L. Schokey. 1986. Amiso acid profiles of heat damaged grasses: J. Dairy. Sci 69:1824.

Weiss, W.P., H.R. Conrad, and W.L. Schokey. 1986 Digestihility of nitrogen in heat damaged alfafa.. J Dairy Sci. 69:2658.

Yu. Y. and J.W. Themas. 1976. Estimation of the extent of hear damunge in alfafa haylage by laborator measurements. J. Anim. Sci. 42:766.
DAN S

Telah

Analisis Pengak mempunyai per: bubuk instant, dalam oven sebe selama 100 jam Yogyakarta. Set 500 detik. Data $\mathrm{Br}, \mathrm{Cu}$ dan $\mathrm{Rb}$ d full cream 4,71 $13,72,0,76$ dan (Kata kunci: Un

The de

Analysis (NAA) is well known. S weighed and fill of samples were irradiated for 30 detector in gamr method. Average $13,8,0,87$ and 2 ppms ; in instant (Key Words: Tre

' Pusat Penelitian 